\title{
QUILOMBOLAS E DIREITOS HUMANOS NO SURINAME
}

\author{
Richard Price \\ College of William and Mary - Estados Unidos
}

Resumo: Desde a independência do Suriname em 1975, o relacionamento entre o Estado e sua população quilombola (cerca de 52 mil pessoas, talvez 15\% da população nacional) deteriorou. Do ponto de vista quilombola, os tipos de atrocidades associadas às guerras coloniais do século dezoito voltaram à tona. A Guerra Civil que começou em 1986, que jogou o exército nacional contra os "Jungle Commandos" (compostos principalmente de quilombolas) só fez piorar a situação dos quilombolas. Um grande julgamento pela Corte Inter-Americana de Direitos Humanos em 1992, tendo como réu o Estado do Suriname, terminou com uma vultosa indenização por danos aos quilombolas Saramaka, autores da queixa. Recentemente a situação piorou, quando os quilombolas - sem qualquer proteção legal sob a constituição do Suriname - viram as terras pelas quais os seus antepassados lutaram e morreram serem confiscadas unilateralmente pelo Estado e doadas, em concessões gigantescas, a companhias madeireiras e mineradoras multinacionais (da Indonésia, da Malásia, da China e do Canadá). O efeito das atuais políticas para os quilombolas não é nada menos do que etnocídio.

Palavras-chave: direitos humanos, quilombolas, Suriname.

Abstract: Since Suriname's independence in 1975, the relationship between the State and its Maroon populations (some 52,000 people, perhaps 15\% of the national population) has deteriorated. From a Maroon perspective, the kinds of atrocities associated with the eighttenth-century colonial wars have resurfaced. The Civil War that began in 1986, pitting the national army against the Jungle Commandos (made up largely of Maroons), has only worsened the Maroons' situation. A major trial before the Inter-American Court of Human Rights in 1992, with the State of Suriname as defendant, ended with a large cash award for damages to the Saramaka Maroon plaintiffs. Recently the situation has worsened, as the Maroons - with no legal protection in the Suriname constitution - have seen the lands their ancestors fought and died for confiscated unilaterally by the State and given, in giant concessions, to multinational 
timber and mining companies (Indonesian, Malaysian, Chinese, and Canadian). The effect of current policies toward Maroons is nothing less than ethnocide.

Keywords: human rights, quilombolas, Surinam.

A República do Suriname continua sendo "o único estado do hemisfério ocidental no qual vivem povos indígenas [e quilombolas] e que de alguma forma não reconhece o direito deles aos territórios de seus ancestrais" (Forest Peoples Programme, 1998). Apesar de ser signatário da Convenção Inter-Americana de Direitos Humanos, o Suriname continua a violar os direitos fundamentais de seus povos indígenas e quilombolas - cerca de 60 mil pessoas, ou $15 \%$ da população nacional - de existirem como povos separados e de continuarem a viver em territórios que, no caso dos quilombolas, lhes eram concedidos formalmente em tratados assinados com sangue há mais de duzentos anos (ver Bilby, 1997).

Os tratados entre os saramacas e os ndyuka, de meados do século 18, foram geralmente respeitados por dois séculos, período durante o qual esses quilombolas desenvolveram as sociedades e culturas talvez mais criativas e distintas de toda a Afro-América (Price; Price, 1999). Mas no Suriname pré-independência dos anos 60 o governo colonial, em colaboração com a Alcoa, desapropriou terras garantidas pelo tratado de 1762, de uns seis mil quilombolas saramaka, a fim de construir a barragem e o lago de uma usina hidroelétrica. E depois da independência do Suriname, em 1975, os sucessivos governos vêm aplicando uma política cada vez mais militante e destrutiva contra os quilombolas e as comunidades indígenas, retirando deles os direitos à terra (e suas riquezas potenciais) e pondo em perigo os seus direitos de existir como povos separados.

No Suriname, estruturas de opressão semelhantes perpassam os períodos colonial e pós-colonial. Não é preciso, para o que ora nos interessam, recitar a ladainha de opressões sofridas pelos quilombolas no início do período colonial que eles chamam de "Primeiro Tempo."' Basta dizer que, durante o

1 Para depoimento detalhado ver, entre outros trabalhos, Price (1983a, 1983b, 1990) e Stedman (1992). Para uma visão geral, Scholtens (1994). 
primeiro século de domínio holandês no Suriname, a classe dos plantadores passou a chamar os quilombolas - o inimigo coletivo da escravocracia - de "vermes", "escória perniciosa", "turba de monstros" e "hidra". Os quilombolas recapturados pelos colonizadores eram "punidos" rotineiramente com o corte dos tendões das pernas, a amputação de membros e uma série de mortes sob tortura. Na verdade, até o final do século 18, a exibição pública de torturas e as execuções de quilombolas recapturados eram comuns em Paramaribo. Hoje, como demonstrei em trabalhos mais extensos, as atitudes motivadoras de tais atos podem ser tudo, menos letras mortas.

A ideologia do Primeiro Tempo continua viva na mente dos homens saramaka do século vinte porque é relevante para suas experiências de vida - ajuda-os a encontrar um sentido, no dia a dia, para o mundo mais amplo em que vivem. Há mais de um século todo homem saramaka gasta anos de sua vida na costa do Suriname trabalhando em madeireiras, na construção ou noutras atividades igualmente mal pagas. Lá ele encontra bakáas - "forasteiros", brancos e negros - que o tratam de uma maneira que ele pode facilmente encaixar na ideologia do Primeiro Tempo. Asipéi, um respeitável senhor de sessenta anos, narrou-me um incidente que ilustra muito bem dezenas de outros casos que ouvi. Quando ele era menino, visitando a cidade com o irmão da sua mãe, um afro-surinamês urbano chamou-o de "macaco". Seu tio respondeu, irada mas orgulhosamente: "No lugar onde vives, tu pagas para beber água e pagas para ter onde cagar; na floresta onde moro, eu bebo a melhor água do mundo quando quero, e defeco à vontade. " Para todos os respeitados historiadores ou especialistas em rituais saramaka, para todos os renomados escultores de madeira ou dançarinos obrigados pela necessidade econômica (e pela falta de escolarização ocidental) a limpar privadas na base de mísseis francesa de Kourou, a ideologia do Primeiro Tempo não pode deixar de ser uma força relevante e poderosa. (Price, 1983a, p. 12).

Os saramakas insistem que as pessoas da cidade que continuam a manipular o poder em Paramaribo - embora sejam na maioria, como eles próprios, descendentes de africanos escravizados - não merecem nenhuma confiança em qualquer circunstância, como a história vem demonstrando repetidamente. Quando o assunto é discutido seriamente, muitas vezes os saramaka apelam para a história de Kwasímukámba, o seu maior triunfo 
sobre o mais esperto de todos os afro-surinameses lobos-em-pele-de-cordeiro (Price, 1983a, p. 153-159). Como explicou um saramaka em 1976, a respeito desta história,

E é por isso, Amigo, que quilombolas não confiam em crioulos [afro-Surinameses não quilombolas]. Por isso é tão difícil para nós avançar no mundo moderno. Nós não acreditamos neles. Por causa do que aconteceu aos nossos antepassados. Se tu te tornas amigo de um deles, é isso que vão fazer contigo. Não deves confiar neles para nada. Gente da cidade! Eles lutaram contra nós ao lado dos brancos... Os quilombolas ainda acreditam que os forasteiros estão sempre tentando aprender os nossos segredos, para um dia poder nos matar. (Price, 1983a, p. 153).

As pessoas modernas da cidade (com raras exceções que incluem alguns poetas e intelectuais) pouco têm feito para mudar este quadro. Até entre os crioulos da classe baixa, que têm maior contato com os quilombolas (e usam ocasionalmente os seus serviços de curandeiros, considerando-os "misteriosos e às vezes bárbaros"), estes são comumente denegridos: "Estereótipos depreciativos são muito utilizados por crioulos urbanos em referência aos quilombolas (Brana-Shute, 1979, p. 119). Entre a elite de Paramaribo, inclusive funcionários do governo, o continuum de rebaixamento parece ir desde uma alegada fraternidade altamente paternalista (graças à educação e à minha criação burguesa aqui estou eu, seu irmão de pele escura da cidade) ao mais profundo desprezo (pelo bruto, sujo e não-civilizado). Piadas étnicas sobre os quilombolas são comuns entre os educados crioulos nacionalistas: "Sabe aquela dos dois caçadores que não caçaram nada o dia inteiro? Pois é, eles sentaram debaixo duma árvore para descansar, e a espingarda de um deles disparou. Felizmente estava virada para cima. Adivinhe o que caiu da árvore. Um ndyuka!"

Em nome da modernização e do desenvolvimento (e para produzir eletricidade barata para as refinarias da Alcoa e a cidade de Paramaribo), cerca de seis mil Saramakas foram retirados à força de suas casas nos anos 60, e o projeto da década de 70 para confinar todos os quilombolas em várias cidades novas no interior, planejadas centralizadamente, só morreu nas pranchetas de desenho por falta de fundos. Um parlamentar Crioulo, respondendo 
sobre a possibilidade deste plano de desenvolvimento colocar a cultura Marrom em perigo, disse: "Cultura? A cultura deles em perigo? Me deixa dizer uma coisa, eles não têm nada que possa ser chamado de cultura. Todo mundo fica falando em cultura, mas isso é uma grande besteira. Essa gente é um grupo de escravos fugidos e tudo que eles têm no interior é um pequeno teto de sapé. Mas agora eles vão poder se beneficiar do novo Suriname" (Westerloo; Diepraam, 1975, p. 157). E no verão de 1992, o chefe da equipe médica do hospital francês de São Laurent, que vêm tratando rotineiramente há muitos anos os quilombolas doentes, falou-me do seu "choque", durante uma inspeção que ele fez com uma equipe de especialistas para monitorar a situação médica em Paramaribo, diante do "desprezo absoluto" demonstrado por surinameses urbanos educados, inclusive médicos e funcionários da Saúde Pública, pelos quilombolas. "Eles os consideram a escória da escória", ele disse, "quase desprovidos de humanidade, e acreditam firmemente que os franceses estão 'acostumando mal' os ndyukas nos campos para refugiados."

A guerra civil, cujas ondas, de maio de 1986 a agosto de 1992, jogaram o exército nacional Surinames contra uma pequena força guerrilheira conhecida por "Jungle Commandos" (formada principalmente de ndyukas mas contando também com alguns saramakas), ofereceu aos citadinos nova oportunidade para pôr em prática as velhas atitudes de muitos deles em relação aos quilombolas. Em 1987 um investigador de direitos humanos dos Estados Unidos relatou a "alegação de várias fontes de que o governo Surinamês não está procurando apenas esmagar os rebeldes, mas está cometendo genocídio contra os quilombolas," e que o chefe militar Desi Bouterse, em emissões radiofônicas, "humilhou todos os quilombolas... ameaçando "matar vocês todos' e 'descobrir os seus jardins e bombardeá-los" (Cerquone 1987, p. 5). "A responsabilidade pela guerra civil recai totalmente sobre o exército liderado pelo Comandante Bouterse", escreveu um renomado intelectual holandês em 1988.

Foi o exército que, em maio de 1986, adotou a política de retaliação coletiva contra comunidades quilombolas... Alimentados por seu aberto desprezo pelos quilombolas e a sua cultura, os militares deixaram com satisfação que a conflagração se espalhasse por quase todo o interior do país... Os templos religiosos 
dos quilombolas tornaram-se alvos especiais. Em Mungo Tapu o templo de Gaan Gadu, um dos mais importantes deuses dos ndyuka, foi destruído. Os quilombolas que ganhavam algum dinheiro na indústria madeireira estavam usando aquele templo como banco para suas poupanças; os soldados levaram 96 mil guilders do lugar sagrado. (Thoden van Velzen, 1988, p. 7-8, 19).

O antropólogo Kenneth Bilby (1990, p. 505-506), quase testemunha ocular de tais eventos, escreveu que:

A virada... aconteceu em novembro e dezembro de 1986, quando uma campanha militar no leste do Suriname resultou em mais de 150 mortes de civis; em várias aldeias ndyuka do Rio Cottica, quilombolas desarmados, inclusive mulheres e crianças, foram cercados e massacrados... Em poucas semanas, mais de 10 mil refugiados quilombolas chegaram à Guiana Francesa. Ouvi terríveis narrativas testemunhais de filas de aldeões indefesos, sendo abatidos pelo fogo de armas automáticas, enquanto rogavam por suas vidas. Eu estava lá quando os refugiados começaram a chegar em Saint-Laurent, e falei com várias dessas testemunhas oculares, apenas alguns dias depois dos massacres. Dessas muitas atrocidades, uma parece ter sido particularmente brutal. No assentamento de Moi Wana, não muito distante de Albina, um soldado arrancou uma criança do colo da mãe, pôs o cano do fuzil em sua boca e puxou o gatilho.

Uma unidade militar de 70 homens (metade deles ameríndios, inclusive alguns especialmente escolhidos por conhecerem pessoalmente os habitantes da aldeia) foi enviado pelo exército com ordens de arrasar o pequeno assentamento de Moiwana, supostamente o quartel-general do chefe do Comando da Selva, em 29 de novembro de 1986. ${ }^{2}$ Usando armas automáticas, granadas de mão e dinamite eles cumpriram metodicamente a tarefa.

\footnotetext{
2 Ver, por exemplo, Amnesty International (1987), Cerquone (1987), Franszoon (1989), Memre Moiwana (1990) e Polirné e Thoden van Velzen (1988). Ameríndios, especialmente caribs (galibi), tinham sido usados como tropas contra os quilombolas pelo exército colonial desde os primeiros tempos da colônia (ver Price, 1990, p. 403-04). Durante toda a recente guerra civil surinamesa. Desi Bouicrse manipulou as relações ameríndias-quilombolas em proveito próprio, especialmente na criação dos Tucujana Amazones que no fim da guerra controlavam toda a parte ocidental do país. e que, juntos com o Comando da Selva e o governo nacional, eram as partes principais do Tratado de Paz de Agosto de 1992.
}

Horizontes Antropológicos, Porto Alegre, ano 5, n. 10, p. 203-241, maio 1999 
"Todo mundo foi fuzilado - homens desarmados, mulheres, mulheres grávidas, um bebê de sete meses... Não se fizeram distinções" (Memre Moiwana, 1990, p. 13). Mais de cinqüenta civis ndyuka desarmados - principalmente crianças pequenas mas também várias jovens mulheres grávidas - foram mortos a sangue frio, alguns esquartejados a machadinha, e todas as casas foram queimadas. Só em dezembro, segundo um relatório do Departamento de Estado norte-americano, 244 quilombolas foram mortos pelo exército nacional e "esquadrões da morte formados por militares estiveram agindo amplamente, sob ordens do governo, contra os quilombolas" (Chin; Buddingh', 1987, p. 116). Em pouco tempo as aldeias de Wanhati, Sabana, Mungo Tapu, Morakondee, Abaadukondee e outras no leste do Suriname estariam todas arrasadas, muitas vezes com o auxílio de aviões leves e helicópteros de combate (alguns deles fornecidos pelos militares brasileiros), outras vezes com bulldozers. Quando um investigador das Nações Unidas foi conduzido através daquela área alguns meses mais tarde, ele relatou que, afora o pessoal militar, "nenhum ser humano ou criatura viva foi visto, exceto alguns cachorros famintos em Albina. A vegetação da selva tomara conta dos prédios destruídos" (Wako, 1988, p. 43).

Dois anos e meio depois da chacina de Moiwana, sob intensa pressão internacional, a polícia civil deteve para questionamento um dos participantes, Orlando Swedo, e colocou a investigação sob a direção do inspetor de polícia Herman Eddy Gooding (que estava trabalhando em outros casos envolvendo os militares). Stanley Rensch, diretor do grupo surinamês de direitos humanos Moiwana'86, relata que Swedo,

que se encontrava sob a custódia da polícia civil, foi tirado fisicamente da prisão por 35 membros da polícia militar fortemente armados e trazido, no meio de ruidoso aplauso, até o local onde o comandante Desi Bouterse falava a um grupo, para ali ser festejado com honras militares. Neste mesmo encontro, Bouterse declarou que o inspetor Gooding deveria ter falado com ele, em vez de prender Swedo, porque Swedo estava apenas cumprindo ordens. Abertamente, ele desafiou a polícia [civil] a dirigir suas queixas diretamente contra ele, o comandante, se quisesse discutir Moiwana. (Memre Moiwana, 1990, p. 5; In Memoriam..., 1992, p. 8). 
Apesar deste aviso, o inspetor Gooding decidiu continuar sua investigação. Pouco depois de sair de um encontro com o comandante da Polícia Militar, na noite de 4 para 5 de agosto de 1990, ele foi encontrado morto a tiros a 30 metros do gabinete do comandante Bouterse. ${ }^{3}$

Paradoxalmente, esses massacres de quilombolas e outras violações de direitos humanos estavam ocorrendo num período em que Bouterse tentava mostrar ao resto do mundo que ele finalmente estava pronto para levar o Suriname de volta a uma democracia de tipo ocidental. Um pouco de história pode ajudar a contextualizar.

Dentro de um curto período após o golpe de estado de 1980, no qual os militares de Bouterse suplantaram o governo democraticamente eleito que estava instalado desde a independência do Suriname em 1975, Bouterse declarou um estado de emergência, suspendeu a constituição, dissolveu o parlamento, destituiu a polícia civil do seu poder e forrou os bairros com "comitês populares" revolucionários e uma "milícia popular." A retórica anti-holandesa (e anti-imperialista) estava na ordem do dia, enquanto o regime costurava estreitas relações com a Cuba de Fidel Castro e a Granada de Maurice Bishop. Já no início de 1981 a Comissão Internacional de Juristas "visitou o Suriname e fez relatos de prisões e detenções ilegais generalizadas, maltrato de presos e cerceamento da liberdade de imprensa" (Nowak, 1989, p. 24). A prisão, a tortura e a execução sumária de quinze cidadãos proeminentes (o presidente da Associação dos Advogados do Suriname, o diretor da Faculdade de Economia da universidade, o presidente da mais importante central sindical, quatro jornalistas, e outros) durante a noite de 8 de dezembro de 1982, efetuadas por

3 A equipe do Moiwana'86 chamou o assassinato a sangue frio do Inspetor Gooding pela Polícia Militar de "o ponto baixo absoluto, em termos de direitos humanos, durante o período 1980-90" (In Memoriam..., 1990, p. 5). Os colegas de Gooding na polícia civil concordaram: logo depois do seu funeral, treze deles, "convencidos de que o futuro era sem qualquer esperança," fugiram com suas famílias para a Holanda (In Memoriam..., 1990, p. 16). Uma investigação da morte de Gooding foi iniciada por uma Comissão de Inquérito especial formada após uma onda de protestos no Suriname e no exterior. Mas depois de um mês os investigadores foram de encontro a o que o Ministro da Justiça e o Advogado Geral publicamente chamaram de "uma parede cega" (Zwambom, 1992, p. 17). "O clima de medo e intimidação levou potenciais testemunhas a pedirem garantia de vida; oficiais da polícia e outros agentes da lei receberam ameaças de morte" (Zwambom, 1992, p. 17).

Horizontes Antropológicos, Porto Alegre, ano 5, n. 10, p. 203-241, maio 1999 
Bouterse e seus associados mais próximos, levou à suspensão da ajuda holandesa para o desenvolvimento - algo em torno de cem milhões de dólares por ano - e ao isolamento internacional do Suriname. ${ }^{4} \mathrm{O}$ dinheiro do tráfico de cocaína e o controle do crescente mercado negro começou a substituir a ajuda holandesa no entender dos militares mas o país, como um todo, entrou em parafuso econômico.

No final de 1985, na esperança de agradar seus credores potenciais (o F.M.I., os holandeses, os americanos), o Suriname levantou a proscrição das atividades dos partidos políticos e Bouterse começou a falar de um retorno à democracia. Embora o capitão Etienne Boerenveen, um amigo íntimo de Bouterse e membro da junta de governo, tenha sido preso poucos meses depois pela U.S.D.E.A. (Administração de Controle de Drogas dos Estados Unidos) em Miami e condenado por tráfico de drogas, implicando os militares do Suriname num largo esquema de narcotráfico, Bouterse resolveu visitar Nova Iorque e falar à Assembléia Geral da ONU. Mas primeiro, para promover internacionalmente a imagem do Suriname, o governo contratou uma firma de relações públicas de Washington D.C. (Van Kloberg \& Associates) - "uma de mais de duas dezenas de firmas de Washington que trabalham no melhoramento da imagem e da receptividade de governos e companhias estrangeiras" (Binder, 1988) - que levou Bouterse à Barney's, em Nova Iorque, para a vesti-lo apropriadamente com um sóbrio terno azul e uma gravata conservadora (em vez das fardas que ele estivera exibindo), arranjou encontros cerimoniais com o prefeito Koch e o cardeal John O'Connor, e escreveu o comovente discurso sobre democracia que ele então pronunciou diante da Assembléia Geral (Binder, 1988). Ao mesmo tempo, o Suriname fez outros

4 Simultaneamente a esses assassinatos, "os escritórios de duas estações de rádio, um jornal, e a Moederbond (a maior central sindical do país) foram incendiados completamente. Cinco jornais diários e semanários foram extintos; duas agências de noticias, fechadas" (Meel 1990, p. 85). A Comissão Internacional de Juristas, depois de uma visita ao local, concluiu que "uma investigação da chacina de dezembro de 1982 era uma pré-condição essencial para a restauração do domínio da lei," e a Comissão Interamericana de Direitos Humanos, depois de sua própria visita, pediu além disso que o Suriname pagasse uma indenização às famílias das vítimas (Nowak, 1989, p. 26-27). As lideranças militares sustentam que "os quinze foram fuzilados ao tentar escapar" (Nowak, 1989, p. 26-27). De maneira geral "Até agora [1989], as autoridades militares conseguiram evitar que a polícia civil e as autoridades judiciárias investiguem crimes cometidos por militares, dizendo-se os únicos responsáveis por essas investigações" (Nowak, 1989, p. 15). (Para mais detalhes, OAS, 1983, 1985 e Wako, 1985.) 
gestos internacionalistas, inclusive (em 12 de novembro de 1987) a ratificação da Convenção Americana de Direitos Humanos. Esta estratégia deu frutos: em meados de 1988, depois da ratificação de uma nova constituição e eleições, os holandeses concordaram em princípio com o reinício da ajuda para o desenvolvimento.

Vários observadores questionaram essas mudanças, se tinham qualquer profundidade, se tudo isso era mais do que uma cortina de fumaça. Em 1989, H. U. E. Thoden van Velzen (1990, p. 160) concluiu que "Depois de mais de um ano de 'controle' civil, a posição dos militares está mais forte do que nunca. O novo governo é pouco mais do que uma conveniente fachada para a ditadura de Bouterse". E fazendo uma retrospectiva dois anos depois, Gert Oostindie (1992, p. 106) afirmou que;

O período 1987-1990 pode ser caracterizado como a continuação de tudo que alguns em 1980 esperavam que seria suprimido para sempre (incompetência política, corrupção), e outros esperavam que mudasse para melhor em 1987 (dificuldades econômicas, desordem civil, a onipresença militar). Infelizmente, o Suriname continuou no seu descenso.

Este período também foi marcado por continuados e repetidos abusos de direitos humanos, em grande parte contra os quilombolas mas também contra outros inocentes civis. Os militares fizeram o possível para intimidar os ativistas de direitos humanos. Em 1988, enquanto Stanley Rensch - diretor do Moiwana'86 - se encontrava em Washington a convite do Departamento de Estado norte-americano, o governo do Suriname promulgou uma ordem de prisão contra ele por atividades subversivas. Depois de uma entrevista coletiva à imprensa, e de arranjar para ser esperado no aeroporto pelo embaixador venezuelano no Suriname e pelo encarregado de negócios da França, ele retomou, apenas para ser receber voz de prisão e ser enjaulado. Um bombardeio contínuo de protestos de governos e grupos de direitos humanos conseguiu colocá-lo em liberdade, mas só depois de onze dias de detenção. ${ }^{5}$ Houve um caso semelhante em 1989, quando o reverendo Rudy Polanen, diretor da

5 Entre o final da década de 80 e o início da década de 90 Rensch foi preso três vezes e torturado na prisão, além de sofrer um atentado praticado por pistoleiros desconhecidos. 
Organização por Justiça e Paz, outro grupo de direitos humanos do Suriname, foi arrancado de um avião pela Polícia Militar, a caminho de um encontro do Conselho de Igrejas do Caribe, acusado de ameaçar a segurança nacional e detido no Forte Zeelandia; seu sucessor. Ilse Labadie, foi ameaçado inúmeras vezes (Mensenrechten..., 1992, p. 8). Em 1990, depois que quatro ameríndios sob custódia militar "desapareceram", um grupo de suas mulheres e mães que fazia uma campanha pedindo uma investigação do Governo foi seriamente ameaçado; duas das mulheres fugiram com as famílias para a Holanda, onde receberam asilo político (Mensenrechten..., 1992, p. 20-21; ver também OAS, 1990, p. 180-181). ${ }^{6}$

Em 1992, eu me envolvi pessoalmente no caso de "Aloeboetoe versus Suriname," no qual reclamantes saramaka eventualmente ganharam a causa contra a República do Suriname na Corte Interamericana para os Direitos Humanos. ${ }^{7}$ Como já escrevi uma descrição detalhada noutro trabalho (Price, 1995), eu resumo aqui.

No dia de Ano Novo em 1987, dois meses depois de o povo do Suriname ter ratificado uma nova constituição "democrática" e um mês depois de ter votado (sob os olhos vigilantes dos militares) em eleições gerais, ocorreu um "incidente" na aldeia saramaka tradicional mais ao norte do país. A petição inicial, submetida pelo grupo Moiwana'86 de direitos humanos do Suriname

6 Vale a pena lembrar que em 1990, quando a Holanda servia de entreposto europeu para os cartéis colombianos de drogas, cerca de $60 \%$ de toda a cocaína confiscada naquele país tinha sido exportada via Suriname (Oostindie, 1992, p. 108). E em 1991 já havia "laboratórios para refinamento de pasta de coca, estoques de produtos químicos para produção e cocaína refinada aguardando embarque para o mercado europeu. Várias pistas de pouso... rasgadas na selva recebem inúmeros vôos semanais da Colômbia. Simplificando, toda a região a sudoeste de Paramaribo, sob controle de Tukuyana Amazones e militares surinameses. está devotada ao processamento e embarque de narcóticos" (Brana-Shute, 1993, p. 61).

7 A Comissão Interamericana de Direitos Humanos está funcionando desde I960. A Corte Interamericana de Direitos Humanos passou a existir oficialmente em 1978, quando o décimo-primeiro estado membro depositou o seu instrumento de ratificação da Convenção Americana de Direitos Humanos na Secretaria Geral da OEA. Os primeiros juízes foram eleitos em 1979 e a Corte realizou sua primeira sessão em 1980. Em 1992 a Corte tinha julgado apenas três "casos contenciosos" - todos contra Honduras por "desaparecimentos forçados." (A Corte descobriu violações em dois desses casos e condenou Honduras a pagar compensações aos parentes próximos.) $\mathrm{Na}$ época, havia quatro casos pendentes, dois contra o Peru e dois contra o Suriname. Outro estava em preparação. contra a Colômbia. A Corte já tinha também publicado doze "opiniões ajuizadas." A decisão da Comissão de Direitos Humanos de processar pela chacina de "Aloeboeloe" da Noite de Ano Novo de 1987, em vez do massacre de Moiwana de 1986, deveu-se à data na qual o Suriname ratificou a Convenção Interamericana (12 de novembro de 1987), aceitando a partir de então a jurisdição mandatória da Corte Interamericana de Direitos Humanos.

Horizontes Antropológicos, Porto Alegre, ano 5, n. 10, p. 203-241, maio 1999 
e datada de 15 de janeiro de 1988, começa descrevendo como mais de vinte quilombolas desarmados foram severamente espancados e torturados (com coronhas de fuzil, baionetas e facas). (Faço aqui um resumo do relatório apresentado em Price, 1995. $)^{8}$

Então eles foram obrigados a deitar no chão enquanto os soldados pisavam nas suas costas e urinavam neles, na presença de umas cinqüenta pessoas. As vítimas tinham acabado de chegar de Paramaribo, onde algumas delas tinham ido receber suas pensões do seguro social. Depois da tortura, uns receberam permissão para ir embora, mas sete, entre eles um menino de quinze anos, foram vendados e arrastados para um veículo militar. Um soldado anunciou que estavam de saída para celebrar o ano novo com eles. No quilômetro $30 \mathrm{o}$ veículo parou e os soldados arrastaram as vítimas para fora. Eles receberam pás e ordem para cavar. Quando uma das vítimas perguntou por que estavam cavando, um soldado disse que eles iam plantar cana. Outro soldado repetiu que eles iam celebrar juntos o Ano Novo. Um homem chamado Aside não esperou para ser morto e tentou fugir. Eles o crivaram de balas mas não foram atrás dele, pensando que ele estava gravemente ferido e morreria. Logo depois ele ouviu tiros e gritos. Os seis restantes, inclusive o menino de quinze anos, foram mortos. Quatro dias depois, saramakas dando busca naquela área encontraram Aside ainda vivo, gravemente ferido e em condições críticas. Eles encontraram também os cadáveres dos outros, já parcialmente devorados pelos abutres. Aside tinha sido atingido na coxa, acima do joelho direito, e a grande ferida estava cheia de vermes. Um X no ombro direito fora gravado com o seu próprio canivete por um soldado.

O grupo relatou a descoberta ao ativista de direitos humanos Stanley Rensch, que após vinte e quatro horas de negociações com as autoridades [Governo/ Militares] recebeu permissão para que um representante da Cruz Vermelha Internacional trouxesse Aside para a cidade, onde ele foi admitido no Hospital Universitário na noite de 6 de janeiro. A Polícia Militar ficou de guarda na porta do seu quarto de hospital e não permitiu a entrada de parentes que foram visitá-lo.

\footnotetext{
8 A petição original, escrita por Stanley Rensch, o diretor do Moiwana'86, de língua sarumaca, está incluída no Report No. 03/90, Case 10.150, Suriname, Inter-American Commission on Human Rights, OEA/Ser.L/V/II.77/Doc. 23, 15 May 1990, p. 1-3, que contém um bom número de depoimentos de apoio doutras testemunhas.
}

Horizontes Antropológicos, Porto Alegre, ano 5, n. 10, p. 203-241, maio 1999 
Enquanto Aside morria lentamente de suas feridas na cama do hospital em Paramaribo ("um cano de gesso em cada uma das pernas, o ombro direito enfaixado, com febre e evidentemente muita dor"), ele foi entrevistado por David Padilla, Secretário Executivo Assistente da Comissão Interamericana para Direitos Humanos - que fora convidado ao Suriname para outros negócios: para assistir a inauguração do governo civil recentemente eleito. As notas dele acrescentam alguns detalhes.

Quando o caminhão parou perto do quilômetro 30, Aside, que não estava amarrado, tirou a venda e tentou fugir, mas os soldados atiraram e ele caiu, atingido fias duas pernas e no ombro direito... Quando caiu, Aside fingiu de morto... Mais tarde, ele ouviu uma rajada de tiros. Ele ouviu um dos prisioneiros, chamado Beri, gritar. Depois, ouviu os soldados comemorar e ouviu outro tiro... Aside disse que eu era a primeira pessoa a entrevistá-lo oficialmente. Ele não tinha sido questionado até então por nenhum advogado, ou militar, ou investigador da polícia... Ele disse ainda que os soldados the tinham roubado todo o dinheiro e o tudo que ele possuía. ${ }^{9}$

Se o maior medo dos quilombolas, como me foi dito na década de 60 , era que "Aqueles tempos [os dias de escravatura e a luta pela liberdade] hão de voltar," então o massacre do Ano Novo de 1987 pode servir de emblema para as maneiras com que as continuidades específicas de "outridade" (othering)

\footnotetext{
9 A entrevista foi feita em 28 de janeiro de 1988. As notas de Padilla estão contidas num documento ajuramentado, assinado em Washington D.C. e datado de 26 de março de 1991, que constitui o "Anexo 1" do "Memorial da Comissão Interamericana de Direitos Humanos. Caso No. 10.150, Aloeboetoe et al. vs. o Governo do Suriname." Trechos de uma entrevista gravada em vídeo feita por delegados da Comissão Interamericana de Direitos Humanos com o irmão de Aside, em 15 de dezembro de 1988 em Paramaribo, adicionam uns últimos detalhes: "Eles o tinham espancado. Uma perna e um braço estavam quebrados... O homem (soldado) bateu nele com muita força. Por isso que ele teve os ossos quebrados. (Q: Mas ele tinha levado tiros?) Sim, ele levou um tiro no lado de dentro da coxa, numa das coxas... (Q: Quem o levou'/) Eles eram soldados mas todos eles tinham esfregado umas coisas pretas na cara. (Q: Mas eles estavam usando uniforme militar'/) Sim, eles estavam de uniforme." Eu assisti esse vídeo em outubro de 1992 na sede da OEA em Washington. D.C. A transcrição/tradução fornecida pela Comissão Interamericana de Direitos Humanos omite um certo número de detalhes porque utiliza uma grosseira tradução simultânea para o inglês feita na própria fita. Eu traduzi diretamente do sranan, a língua falada na fita tanto pelo irmão de Aside quanto pela pessoa que apresentava-lhe as questões.
}

Horizontes Antropológicos, Porto Alegre, ano 5, n. 10, p. 203-241, maio 1999 
produziram e continuam a produzir, no Suriname, exatamente as condições que dão fundamento a tais medos. De certa forma o "festejar" dos soldados, enquanto os jovens quilombolas eram metralhados, vem acontecendo há três séculos.

Vejamos agora o resultado do massacre do dia de Ano Novo de 1987, que revela um pouco da frustradora lentidão dos processos legais envolvendo direitos humanos. ${ }^{10}$ Dentro das primeiras cinco semanas após o ocorrido, a Comissão Interamericana de Direitos Humanos transmitiu ao governo do Suriname partes relevantes do relatório de Rensch sobre o incidente, junto com uma série de questões: As testemunhas (Aside, por exemplo) foram entrevistadas pelas autoridades? Os corpos das seis pessoas mortas foram entregues às suas famílias? E poderia o Governo remeter à Comissão cópias dessas entrevistas bem como cópias das autópsias e o boletim médico de Aside (que ainda estava vivo)?

Em 20 de julho de 1988, não tendo recebido qualquer resposta, a Comissão, por uma questão de cortesia diplomática, reiterou o seu pedido de informação "dentro dos próximos trinta dias." No dia 19 de agosto, o representante permanente do Suriname respondeu:

O Representante Permanente da República do Suriname na OEA apresenta os seus cumprimentos ao Secretário Executivo [etc. etc.] e... tem a honra, diante das instruções recebidas do Governo do Suriname, de informar a CIADH que: O Sr. Aside foi interrogado pela Polícia Militar e um relatório oficial foi preenchido. Enquanto estava hospitalizado, o acima mencionado Aside faleceu. De acordo com o exame post-mortem, Aside morreu por falta de oxigênio no sangue.

O Representante Permanente gostaria de dizer ainda que a investigação inicial sobre a morte das seis supostas vítimas em Pokigron foi feita pela Polícia Militar. Em conseqüência desta investigação sete soldados foram postos sob custódia para interrogatório. Como a conclusão desse interrogatório não apresentou

${ }^{10}$ Eu utilizo aqui os seguintes documentos: "Report No. 03/90, Caso 10.150. Suriname" (OEA/ Ser.L/V/ II.77/Doc. 23. 15 Maio 1990): "Memorial da CIADH. Caso No. 10.150. Aloeboetoe et al. vs O Governo do Suriname" (1991); "Contra-Memorial do Suriname" (1991): "Comentários do Suriname sobre a Apresentação de Evidência” (1991): “Corte Interamericana de Direitos Humanos, Julgamento de 4 de dezembro. 1991. Caso Aloeboetoe et al.” 
nenhuma base para a continuidade da detenção, os soldados foram soltos... Neste estágio a investigação do caso 10.150 foi declarada encerrada pela Promotoria Militar... O Representante Permanente da República do Suriname na OEA aproveita a oportunidade para dirigir ao Secretário Executivo da C1ADR os seus sentimentos da mais alta consideração.

Em dezembro de 1988, durante uma visita ao Suriname, a Comissão entrevistou longamente o Presidente da República, o Vice-presidente, o Presidente da Assembléia Nacional, o Ministro das Relações Exteriores, o Ministro da Justiça, o Advogado Geral da União e o Presidente da Suprema Corte. A CIADR perguntou a essas autoridades por que eles tinham libertado os soldados que tinham sido detidos, após um simples interrogatório. Não houve resposta. Tampouco houve respostas para outras questões embaraçosas sobre o caso - por que, por exemplo, os corpos não tinham sido liberados para as famílias e por que o Oficial Leeflang, responsável pela unidade militar em questão, jamais fora interrogado. Após algum vai-e-vem burocrático, a Comissão informou ao Governo do Suriname que estava se colocando à disposição das partes envolvidas "com o objetivo de chegar a um acordo amigável sobre a questão em termos de possíveis reparações" e propôs uma reunião durante suas sessões de abril em Washington. O Governo não se fez representar pessoalmente mas enviou um fax:

O Governo do Suriname está atualmente submetendo à Assembléia Nacional um projeto de Anistia... O Governo tomou conhecimento da proposta de acordo amigável... no entanto [acredita que] esta proposta visa a solução de um caso isolado de uma série de ocorrências resultantes de atos de guerra. Por este motivo, o Governo do Suriname solicita à CIADH que reconsidere o caso em pauta na perspectiva do mencionado projeto de Anistia.

O advogado das vítimas deplorou a ausência do Suriname na audiência, especialmente tendo em vista que a data fora estabelecida em comum acordo, e declarou ainda que o fax do Governo era a confirmação da responsabilidade do Suriname pelos assassinatos. Se as vítimas tivessem perdido a vida num autêntico ato de guerra, ele argumentou, não haveria necessidade de o Governo propor uma lei de anistia. Nas sessões de setembro, a Comissão ouviu 
argumentos formais de que o Governo violara inúmeros artigos da Convenção Americana (inclusive o direito à vida e ao tratamento humanitário) e que a Lei de Anistia não livraria o Governo do Suriname de suas obrigações diante da Lei Internacional e da Convenção Americana. O representante do governo do Suriname pediu um prazo razoável para consultar Paramaribo sobre sua posição.

Em novembro de 1989, o professor Claudio Grossman (advogado dos queixosos) e o Dr. David Padilla (representando a Comissão) reuniram-se com o Dr. E.J. Sedoc, ministro das Relações Exteriores do Suriname, para discutir um acordo amistoso para o caso; o Dr. Sedoc prometeu uma resposta rápida de seu governo, mas não veio resposta alguma. Seis meses mais tarde, a Comissão convocou as partes para uma audiência. O Governo do Suriname não compareceu, mas submeteu à Comissão uma longa lista de argumentos inconsistentes, inclusive o de que "O Governo que tomou posse em 26 de janeiro de 1988 não pode ser responsabilizado pelas ocorrências em questão." De posse dessa resposta altamente duvidosa, e citando vários artigos violados da Convenção Americana além do desrespeito metódico aos pedidos de informação e de investigação dos fatos, feitos pela Comissão, o professor Grossman solicitou que o caso fosse enviado para a Corte Interamericana de Direitos Humanos como contencioso, para resolução litigiosa. O Governo do Suriname recebeu uma última chance para investigar as violações, punir os responsáveis e pagar uma justa compensação às famílias das vítimas no prazo de noventa dias. Este período expirou sem resposta no dia 27 de agosto de 1990, e a Comissão levou o caso à Corte Interamericana de Direitos Humanos.

O contraditório surinamês, submetido à corte, começou relatando longamente as ratificações de compromissos internacionais com os direitos humanos da parte da jovem nação. Ele quis mostrar que, no papel e em princípio, o Suriname tinha exibido um respeito exemplar pelos direitos de seus cidadãos. Em seguida, tentou demonstrar o que chamou de "natureza irracional e desequilibrada" dos argumentos da Comissão neste caso. Boa parte do contraditório foi dedicado a levantar uma cortina de fumaça através de irrelevantes objeções formais, mas ao tratar de fatos foi inequívoco. Argumentando às vezes como se houvesse apenas uma única vítima, disse que: 
Não há nenhuma testemunha confiável ou declaração da vítima, Sr. Aside, que sustente a alegação da Comissão de que a vítima foi presa e executada por ordem do exército Surinamês. A informação contida na gravação em vídeo do testemunho do irmão de Aside não ajuda em nada na corroboração das vagas acusações contra o Suriname... A morte do Sr. Aside não representa nenhuma violação de direitos humanos imputável ao Suriname, pois a Comissão não produziu qualquer evidência de infração de direitos... Até hoje, não houve nenhum depoimento capaz de corroborar a veracidade das acusações contra o Suriname, e o que está registrado não passa de diz-que-diz... Portanto: O Suriname não pode ser responsabilizado pelo desaparecimento e a morte das pessoas indicadas pela Comissão.

Em 2 de dezembro de 1991, a Corte agendou uma audiência pública na Costa Rica para a apresentação oral das objeções preliminares. Porém o Suriname - representado pelo seu Advogado Geral, um patologista e membro do Ministério das Relações Exteriores - usou a oportunidade para reverter abruptamente sua posição, aceitando laconicamente a responsabilidade pelos eventos que levavam àquele julgamento. $\mathrm{O}$ advogado Surinamês anunciou de repente:

A República do Suriname... aceita a responsabilidade pelas conseqüências do caso de Pokigron, mais conhecido como Aloeboetoe et al.... Eu desejo apenas reiterar que o Suriname aceita sua responsabilidade nesta instância.

Após um pedido de esclarecimento feito pelo atônito delegado da Comissão, ele disse apenas:

Eu creio que minha declaração foi clara: a responsabilidade foi aceita. Portanto, a Corte tem o direito de encerrar o caso, arquivá-lo e determinar a compensação a ser paga ou o que for legalmente apropriado.

A Corte concluiu, unanimemente, que a República do Suriname tinha agora admitido sua responsabilidade e que a disputa relativa aos fatos do caso estava concluída, mas que o caso ficaria temporariamente suspenso para determinação dos custos e das reparações. A última e, para nós, mais reveladora rodada de complicações legais ia começar. 
O laudo da Comissão sobre as reparações é de aproximadamente 200 páginas e apresenta argumentos detalhados para o pagamento de somas específicas por danos materiais aos dependentes das vítimas (compensação por perdas financeiras), por danos morais (compensação pelo impacto psicológico dos assassinatos e suas conseqüências, inclusive a negação dos direitos dos familiares de enterrar os corpos), por danos morais ao povo saramaca como um todo (pela incursão do exército em território saramaca, pela tortura pública e execução de homens desarmados) e vários custos legais, bem como certas medidas não-pecuniárias (reconhecimento público da culpa do Governo, identificação e julgamento das pessoas responsáveis). A identificação dos dependentes foi feita com extremo cuidado, na medida em que Stanley Rensch (ele próprio um saramaca) e uma equipe de trabalhadores em direitos humanos completavam três viagens ao interior destroçado pela guerra para obter depoimentos juramentados das famílias e participar em prolongadas deliberações sobre a justa compensação para cada caso. A Comissão foi capaz de apresentar, para cada vítima, uma lista detalhada de dependentes, cálculos de renda anual e outros dados pertinentes. Nesta altura dos acontecimentos, eu fui chamado para ajuda a assegurar que as noções saramacas de dependência legal - que diferem da prática Ocidental (inclusive da dos surinameses urbanos) seriam representadas de forma apropriada nos procedimentos da Comissão, e para estabelecer um caso de danos morais sofridos pelo povo saramaca como um todo.

O Governo do Suriname respondeu com um contralaudo de dez páginas, assentado numa retórica triunfalista alardeando o sucesso da política de direitos humanos da administração mais recentemente eleita e anunciando uma "nova" postura em relação aos quilombolas, com o argumento de que, embora pudesse ter havido desprezo e abuso nas administrações anteriores, as coisas tinham mudado. ${ }^{11}$ Os quilombolas gozavam agora de todos os privilégios

\footnotetext{
11 Apesar dessas reivindicações, um levantamento cuidadoso das posições do governo Venetiaan em relação aos direitos humanos oferece um quadro desapontador. Depois de observar que "o atual governo do presidente Venetiaan herda numerosos casos de violações de direitos humanos ainda não resolvidos: dos assassinatos de dezembro de 1982 até os massacres de Moiwana 1986 e Pokigron 1987, até as chacinas e desaparecimentos de vários indivíduos em 1989 e 1990," o relatório conclui que "o governo atual não deu ainda nenhum sinal de seguir os casos não resolvidos com maior vigor dos que os governos anteriores" (Zwamborn 1992, p. 5-6; ver também OAS, 1992, p. 250-253).
} 
da completa cidadania surinamesa e eram considerados pelas pessoas do partido da situação como seus irmãos. (O que fica sem explicação aqui é que a propriedade do território quilombola passaria por isso ao estado, que por isso a lei quilombola perderia a sua força, que os filhos de casamentos políginos se tornariam bastardos, e que inúmeros outros aspectos dos direitos dos povos quilombolas a uma existência separada seriam extintos. ${ }^{12}$ )

As considerações introduzidas pela Comissão a respeito de certos costumes tribais saramacas concernentes a estrutura familiar (poligamia, etc.) são irrelevantes para o presente caso [i.e. como as leis do Suriname não reconhecem as mulheres políginas nem seus filhos, essas pessoas não contam como dependentes legais]... Ademais, o Suriname considera que a aceitação unilateral de responsabilidade feita em dezembro de 1991 constitui acatamento total e apropriado ao princípio de dar "compensação moral" às famílias das vítimas e à tribo saramaca...

Em conclusão, o Suriname acredita que no presente caso suas dívidas devem ser de caráter in natura, completamente não-financeiras, podendo-se prever o fornecimento de materiais de construção, terra agricultável, benefícios de seguro social, serviços médicos e de educação... Nós acreditamos que este auto-exame de consciência não deve servir de pretexto para pagar milhões em indenizações e empobrecer mais ainda a nossa nação.

${ }^{12}$ Há uma longa história de tentativas da elite colonial e nacional em Paramaribo para anular unilateralmente os entendimentos entre a coroa holandesa e os quilombolas nos tratados do século dezoito. Interpretações eruditas de várias constituições surinamesas e do status dos tratados - apresentadas, é claro, por não quilombolas - todas elas minimizam consistentemente os direitos quilombolas (ver, por exemplo, Quintus Bosz, 1954, 1965). A questão surgiu mais agudamente nos debates constitucionais no momento da independência em 1975. O ministro Hoost declarou que os tratados do século dezoito dali em diante perderiam a sua validade "pois eles restringiam os movimentos tanto dos quilombolas quanto dos outros surinameses". E ele anunciou que, como "o governo parara há muito tempo de restringir o movimento dos quilombolas fora de suas reservas, não seria do interesse dos quilombolas que os tratados vigorassem." Em todo caso. ele concluiu, "a maioria dos seus direitos tradicionais estariam protegidos sob os termos mais gerais dos artigos sobre direitos fundamentais da nova constituição" (Dew, 1978, p. 194). Os quilombolas jamais foram consultados. Como escreveu o doutor em leis H. F. Munneke (1991, p. 97-98): “A antipatia dos políticos do Suriname pela diversidade legal torna-os insensitivos aos problemas de os quilombolas e os índios quererem preservar suas próprias culturas legais nos territórios tradicionais onde vivem... Na minha opinião o principal problema para os habitantes do interior do Suriname é a crença de que as suas terras estão sendo exploradas por gente da capital sem qualquer lucro daquela exploração para eles mesmos."

Horizontes Antropológicos, Porto Alegre, ano 5, n. 10, p. 203-241, maio 1999 
A audiência pública teve lugar em San José no dia 7 de julho de 1992, e durou das dez da manhã às oito da noite. ${ }^{13}$ Eu fui a primeira testemunha, e depus durante quatro horas. Boa parte deste tempo foi gasto dando respostas objetivas a uma série de questões cuidadosamente preparadas sobre as realidades saramacas, apresentadas pelo advogado da Comissão: "Você consideraria estranho ou normal um saramaca ser casado com três mulheres?" "Trabalhar na construção civil em Paramaribo é algo que os homens saramacas fazem?" "Há telefones nas aldeias saramacas?" "Qual é o índice de analfabetismo nas aldeias saramacas?" Outras questões exigiram miniconferências sobre história quilombola, ideologia, e vida cotidiana: "No contexto da cultura saramaca, qual seria o impacto da maneira pela qual as vítimas foram mortas... assaltadas... raptadas, e forçadas a cavar suas próprias sepulturas?" "Seria isto agravado se o Governo se recusasse a dar explicações, investigar, ou punir os responsáveis?" "Você poderia comentar a afirmação de que os quilombolas não se sentem tratados com dignidade no Suriname, que eles são submetidos a insultos racistas, e que esses valores estão explícitos no tratamento que lhes é dado em questões políticas, financeiras, sócio-econômicas e ainda naquelas que dizem respeito à educação e ao atendimento médico?" Algumas questões referiam-se à razoabilidade das compensações propostas pela Comissão e se os saramacas eram suficientemente "responsáveis" para lidar com as quantias pedidas. No meu depoimento, eu sublinhei não apenas a minha ligação de longa data com a vida e a cultura saramacas, mas também o fato de ter passado as duas últimas semanas na companhia de um grupo de saramacas, inclusive o Gaamá (Chefe) Songo Aboikoni, em Washington D.C., aonde eles tinham ido

\footnotetext{
13 Este relato é baseado em transcrições oficiais não corrigidas da Corte (mais de 200 páginas datilografadas) e em minhas próprias anotações tomadas na hora. A transcrição/tradução está parcialmente em espanhol e parcialmente em inglês, embora alguns depoimentos chaves tenham sido em holandês. As transcrições do julgamento são textos brutos, em espanhol e inglês de gravador. Claudio Grossman (que questionou as testemunhas em nome da Comissão) fez muitas de suas perguntas diretas em holandês, e as testemunhas do Suriname também falaram em holandês (exceto Stanley Rensch, que falou em inglês). Estava presente uma jovem de Curaçao, membro da equipe da Corte, que serviu de intérprete ad hoc (não-profissional) entre o holandês e o espanhol, e são as palavras dela que estão escritas na transcrição. Como essas partes da transcrição resumem radicalmente os verdadeiros depoimentos, como foi visto pela comparação com minhas anotações durante o julgamento, o relato que faço aqui é construído de uma combinação dessas fontes. Felizmente, como Grossman, eu fui capaz de compreender os depoimentos nas três línguas relevantes: holandês, espanhol e inglês.
}

Horizontes Antropológicos, Porto Alegre, ano 5, n. 10, p. 203-241, maio 1999 
participar do Festival of American Folklife, e discuti longamente com eles o depoimento que eu tinha pela frente (ver Price; Price, 1995).

Ironicamente, muitas das questões que me foram postas pelo advogado do Suriname ajudaram-me a fortalecer o caso da Comissão: "Doutor, como é que alguém pode saber o verdadeiro número de esposas dum membro da tribo saramaca?" ou "Doutor, não há no interior do país nenhum lugar onde se registrem os casamentos saramacas?"

Outra questão do Suriname ensejou a explanação de pontos mais fundamentais: "Doutor, você disse que a incursão do exército do Suriname em território saramaca constitui invasão ilegal. Isto significa que o território saramaca é independente do Suriname? Os saramacas possuem leis que são independentes do governo central do Suriname?"

As perguntas dos juízes foram cuidadosas; eles também requisitaram uma coleção completa dos nossos livros publicados sobre os saramacas. Eles pareciam especialmente interessados na natureza dos direitos territoriais e jurídicos tradicionais dos saramacas, e nos modos pelos quais os saramacas conceituam a soberania, em como funciona a estrutura familiar e como isso pode afetar a distribuição de reparações, e como o problema da moeda não-conversível do Suriname e a hiperinflação daquele país podiam afetar os valores de compensação ao longo do tempo. Ao final do meu depoimento, tanto eu como os advogados da Comissão sentíamos que os ventos sopravam a nosso favor.

O depoimento mais breve de Stanley Rensch ao advogado da Comissão foi objetivo, e tratou principalmente dos detalhes de suas viagens ao interior para conseguir atestados de identificação dos dependentes. O questionamento do advogado do Suriname foi bastante contencioso e concentrou-se na tentativa de fazer furos no meu depoimento anterior, argumentando, por exemplo, que como os saramacas votaram nas eleições mais recentes, o território saramaca devia estar cheio de locais de registro. Durante todo o interrogatório Rensch deu respostas dignas que, sem que ele soubesse (porque não lhe foi permitido presenciar o meu depoimento), confirmaram tudo que eu acabara de dizer. Argüido pelos juízes, ele destacou a necessidade de algum tipo de garantia do Governo para os vários direitos dos quilombolas. Juiz Cançado Trindade: "Como poderia ser a garantia, para que o que aconteceu não se repita?" SR: "Eu acho que a sociedade surinamesa deve dar a essas pessoas a 
sensação de que ela se importa, de que tudo aquilo que as atingir no futuro será punido, que se o direito delas for violado os responsáveis serão punidos... na forma da lei do Suriname, seja ela qual for."

Mas o depoimento mais decisivo do dia veio da principal testemunha do Suriname, Ramón de Freitas, que ocupara o cargo de auditor militar [Juiz Advogado Geral] em todas as administrações políticas desde o golpe de estado de Bouterse em 1980. O advogado do Suriname iniciou o amigável questionamento perguntando sobre a investigação das sete mortes, que aconteceram sob sua autoridade.

de Freitas: Alguns suspeitos foram presos e ficaram detidos mas foram liberados posteriormente, porque os cadáveres apresentados não eram os das pessoas que teriam sido mortas.

Advogado: Houve mais alguma investigação?

de Freitas: Sim, e ela continua, [com um sorriso cínico:] Esses casos se alongam durante anos.

Advogado: Fale-nos sobre a situação atual dos direitos humanos no Suriname.

de Freitas: Houve grandes avanços. Na constituição, o poder dos militares foi eliminador. ${ }^{14}$

Advogado: Qual é a atitude do Governo em relação a este caso?

de Freitas: O Governo do Suriname considera que isso faz parte da democratização. Senão, jamais teria aceito a responsabilidade...

Juiz Buergenthal [com frustração na voz]: Sr. Presidente [da Corte], eu não entendo de que governo do Suriname nós estamos falando ou qual é a relevância da situação no Suriname hoje, se é ou não é uma democracia... Eu já não sei mais o que estou ouvindo!...

Advogado: Sr. de Freitas, qual é a validade atual do Tratado de 1762 no Suriname?

14 Na verdade, “O artigo 177 da Constituição de 1987 diz que 0 Exército Nacional é a vanguarda militar do povo do Suriname, defendendo a soberania e os direitos supremos do povo. e contribuindo para a reconstrução e a liberação nacionais. Uma oportunidade ainda maior para interferência (militar) é proporcionada pelo Artigo 178" (Zwamborn, 1992, p. 12). 
de Freitas: É uma longa história. Em 1760 e 1762 os colonizadores holandeses assinaram tratados com os negros - com os ndyukas e os saramacas. Esses tratados estabeleciam um tipo de apartheid entre aqueles negros e os holandeses. Apartheid porque foi dada aos negros uma jurisdição separada no país. Eles receberam permissão para punir seu próprio povo e lidar com questões civis, mas não para ir a Paramaribo. Havia uma separação entre o interior e o litoral. Tais tratados estabeleceram estados dentro de um estado e assim os negros controlavam os seus próprios territórios. O que eles tinham eram "homelands". Foi neste contexto que o título de Granman ou Governador dos Negros surgiu. Mas esses tratados não eram respeitados porque os negros eram muito agressivos e, a fim de acabar com a escravidão, faziam guerrilhas. É bom lembrar que foram os descendentes daqueles mesmos holandeses que foram mais tarde para a África do Sul e lá criaram um regime de apartheid. Estes dois [saramaka e ndyuka] tratados foram na verdade experiências ou testes do apartheid. Quero frisar este ponto porque é a idéia de apartheid que estabelece qualquer direito que esses negros dizem possuir... Em 1975, quando o Suriname se tornou independente, foi posto um ponto final em tudo isso. Em outras palavras, as leis do Suriname, inclusive leis de herança, são as únicas atualmente aplicáveis a todos os Surinameses.

Advogado: Quais são as leis relativas à poligamia?

de Freitas: A poligamia não é reconhecida pelo Suriname... Nenhum juiz lhe daria validade.

Advogado: Existe uma maneira de reconhecer as crianças nascidas fora do casamento?

de Freitas: Crianças nascidas fora do casamento não são reconhecidas com respeito a herança...

Advogado: Há cartórios de registros no interior onde casamentos e nascimentos são registrados?

de Freitas: Em cada aldeia do interior há um registro civil. Podemos deduzir isso do fato de todos os negros e índios do interior terem participado em massa das eleições...

Advogado: O que você acha da idéia de que o Presidente do Suriname deve reconhecer publicamente os incidentes neste caso? 
de Freitas: Eu li esta proposta e preciso ter muito cuidado com o que digo, para não falar em meu nome. Então eu devo afirmar apenas que esta exigência de desculpas não é necessária porque o presidente e o seu partido político consideram os quilombolas como irmãos. $\mathrm{Na}$ verdade, o presidente e o seu partido político tiveram uma votação expressiva no interior do país, exatamente onde essas pessoas foram mortas... Além disso, o presidente visitou recentemente o interior.

De certa forma o questionamento posterior feito pela Comissão explodiu antes de sair da plataforma de lançamento, quando o seu advogado perguntou a de Freitas há quanto tempo ele ocupava o seu cargo atual. De Freitas (provavelmente para prevenir-se contra questões sobre investigações abafadas no passado) protestou iradamente dizendo-se representante do governo do Suriname e exigindo saber em que capacidade o professor Grossman, o advogado, pretendia questioná-lo. O juiz Buergenthal, obviamente irritado com de Freitas, interrompeu, "Com licença, com licença, deixe-me observar que aqui você é uma testemunha, nós fazemos as perguntas e você responde quando lhe perguntarem." O juiz Barberis reiterou, "Eu gostaria de deixar bem claro que este homem [de Freitas] não é o representante do Suriname. Se fosse, ele estaria sentado ali [com os advogados]. Ele está aqui como testemunha." De Freitas - um homem evidentemente desacostumado com contrariedades - insistiu, "Eu estou aqui como representante do estado do Suriname. Tudo que eu digo aqui é uma representação do Estado do Suriname." O presidente da Corte avisou de Freitas energicamente que ele não poderia usar dois chapéus e perguntou-lhe se estava disposto a continuar depondo como testemunha, não como representante oficial. Depois de consultar a equipe de advogados do Suriname, de Freitas concordou a contragosto em prosseguir, e Grossman perguntou mais uma vez há quanto tempo ele mantinha o cargo que atualmente ocupava. Isso levou a nova troca de farpas e a um surto de raiva mal controlada, até que o próprio Grossman, com o rosto vermelho, disse que não podia continuar. Dez minutos antes ele tinha feito uma simples pergunta e desde então de Freitas não parara de questioná-lo. Ele estava cheio daquela testemunha, disse; não tinha mais perguntas.

Os juízes, no entanto, continuaram a examinar de Freitas. 
Juiz Barberis: O seu código civil é influenciado pelo código civil holandês?

de Freitas: Seja qual for a sua base, ele é totalmente adaptado ao Suriname... E aquele código reconhece apenas danos reais, materiais [não morais].

Juiz Barberis: Um momento! Um momento! Eu estou perguntando uma coisa e você está respondendo outra. Minha pergunta é se o código civil do Suriname é baseado no código civil holandês.

de Freitas: A resposta é não...

Juiz Barberis [sarcasticamente]: Quer dizer que o código do Suriname é sui generis? Ou talvez seja baseado na lei francesa? Na lei alemã?

de Freitas: Ele é sui generis. [risos na audiência... De Freitas fica tenso]

Juiz Barberis: Se, como você diz, a lei agora aplica-se aos saramacas, como eles foram informados disso? Existe uma tradução do código civil para o saramaca? de Freitas: A língua oficial do Suriname é...

Juiz Barberis: $\dot{E}$ por isso que eu pergunto! Responda-me sim ou não. Existe uma tradução do código civil em saramaca.

de Freitas: Não.

Juiz Barberis: Muito bem. Como pode então a população saramaca ficar a par das leis do Suriname?

de Freitas: Através do holandês, que eles aprendem na escola.

Juiz Barberis: A maioria dos saramacas fala holandês?

de Freitas: Pelo que sei eles falam holandês, especialmente de 1986 para cá. ${ }^{15}$

Juiz Barberis: Você disse que as leis do Suriname valem para todo o território nacional, mas são elas ou as leis consuetudinárias que vigoram no interior?

de Freitas: Todos os surinameses estão sujeitos à mesma lei, inclusive no interior. E os saramacas são surinameses...

Juiz Nieto: Se eu o entendi bem, o código civil proíbe a poligamia?

de Freitas: Sim.

15 É bom notar que em 1986, com o advento da guerra civil, as poucas escolas que existiam no interior foram iodas fechadas pelos militares. 
Juiz Nieto: Mas há poligamia na prática?

de Freitas: Eu não sei...

Juiz Nieto: Todo mundo no país está registrado no registro civil?

de Freitas: Não sou especialista neste assunto, mas, pelo que ouvi, todo mundo deve ser registrado...

Juiz Barberis: Quero fazer uma observação. A corte já ouviu três testemunhas [Price, Rensch, e de Freitas] que deram duas imagens completamente diferentes da realidade. De acordo com as duas primeiras existem leis consuetudinárias e uma situação muito particular [entre os saramacas]. De acordo com a última testemunha, as leis do Suriname se aplicam lá como se fosse na periferia de Geneva ou Neuchatel.

Esses procedimentos um tanto bizarros foram concluídos pela argumentação final de cada um dos lados. A Comissão expôs brevemente seus argumentos, principalmente apoiada em laudos detalhados, mas não deixou a Corte esquecer o tom da precedente discussão. Falando em nome da Comissão, o embaixador Oliver Jackman observou que:

A Corte ouviu as testemunhas, viu as testemunhas, e está em condições de julgar tanto o valor dos depoimentos quanto a aparência e a credibilidade das testemunhas que apresentaram evidências... Acredito que os meritíssimos juízes estão perfeitamente afiançados pela lei, pelo precedente e, de fato, pelo bom senso [a dar um veredicto] numa situação como esta, em que foi apresentado, por um lado, um laudo muito detalhado apoiado em detalhada evidência especializada, e em que, por outro lado, foi apresentada uma réplica frágil em detalhes e argumentos. Em poucas palavras, estou certo de poder deixar esta questão nas mãos da Corte.

O advogado do Suriname concluiu simplesmente que, na opinião do presidente do Suriname "a indenização no presente caso deve ser in natura, não financeira, e incluir coisas como habitação apropriada, terra agricultável, seguro social e serviços médicos e de educação". Como tinha terminado o período de réplicas, ninguém teve a chance de perguntar por que tais coisas já não eram direitos dos saramacas, na sua condição de cidadãos do Suriname. 
Suspensa a sessão da Corte, todos se levantaram enquanto os juízes togados saíam em fila. O Juiz Advogado Geral de Freitas atravessou a sala e estendeu-me a mão. "Você sabe", ele disse sorrindo, "desde a Revolução [nome dado pelo governo Surinamês ao golpe de estado de Bouterse, em 1980] os quilombolas não vivem mais como povos separados. Desde a última vez que você esteve no Suriname, todos eles se mudaram para a cidade, todos vão à escola, todos sabem 1er e escrever, e não existe mais poligamia. $\mathrm{Na}$ verdade, o presidente Venetiaan os considera seus irmãos." E ele acrescentou então uma mensagem mais pessoal. "Os meus colegas e eu no exército sabemos muito bem das muitas coisas que você escreve e esperamos que você volte ao Suriname em breve. Pode estar certo de que estaremos preparando uma recepção muito especial para você, a qualquer hora que você chegar." David Padilla, que ouviu a conversa, se ofereceu para me levar para tornar um whisky. ${ }^{16}$

Em 10 de setembro de 1993, a Corte Interamericana de Direitos Humanos pronunciou uma sentença de quarenta páginas sobre "Aloeboetoe" ordenando o Governo do Suriname a pagar uma indenização total de US\$ 453.102,00 por danos causados a uma meia centena de indivíduos saramacas. A decisão provoca orgulho e desapontamento. Que o Governo do Suriname tenha sido

${ }^{16}$ O Juiz Advogado Geral de Freitas deveria testemunhar em favor do governo no dia seguinte no segundo caso contra o Suriname sendo ouvido pela Corte, "Asok Gangaram Panday v. a República do Suriname" (ver Price, 1995). No último minuto, no entanto, ele se recusou a depor, embora estivesse presente durante todos os procedimentos. Pareceu-me que, depois da dura arguição do dia anterior no julgamento do caso "Aloeboetoe" ele simplesmente resolveu não enfrentar o fogo cruzado que ele esperava do advogado da Comissão. De fato, nas folhas do advogado com as questões que ele pretendia fazer incluíam-se as seguintes (com as respostas que ele já antecipava entre colchetes): "Você. ou alguém trabalhando sob sua direção, chegou a investigar a possibilidade de o Sr. Panday ter sido torturado durante o período em que esteve detido? |não há indicação de tal investigação] Houve algum julgamento - criminal, civil ou militar - no Suriname para determinar responsabilidade por detenção arbitrária ou por morte neste caso? [não] Alguma ação disciplinar foi tomada ou alguma outra sanção foi imposta em relação aos eventos deste caso? [nãol Quem ć o Procurador Geral? [Sr. Reeder] O Sr. Reeder era Procurador Geral quando quinze pessoas foram mortas pela Polícia Militar em 1982? [ver Relatório da Comissão] O Sr. Reeder era Procurador Geral quando soldados eram encontrados mortos, meia dúzia de cada vez, em 1983? [idem] O Sr. Reeder era Procurador Geral quando [Majorl Roy Horb [um dos mais próximos associados de Bouterse que mais tarde tornou-se 'dispensável'! foi encontrado morto [supostamente enforcado por suicídio| enquanto se encontrava sob custódia da Polícia Militar? [idem] Algumu responsabilidade por ação incorreta foi jamais atribuída à Polícia Militar em qualquer desses casos? [não] Quem faz a supervisão civil da Polícia Militar?"... e assim por diante. A questão do papel de de Freitas, como Juiz Advogado Geral. na [não-]investigação das chacinas de 1982 também estava na mente de todo mundo e teria certamente vindo à lona se ele concordasse em testemunhar.

Horizontes Antropológicos, Porto Alegre, ano 5, n. 10, p. 203-241, maio 1999 
julgado culpado pelo assassinato de sete quilombolas civis, que tenha sido condenado a pagar aos seus dependentes quase meio milhão de dólares (em moeda corrente), e que a definição desses dependentes considere algumas das especificidades da estrutura social saramaca é uma vitória para o Moiwana'86 e para a Comissão. Que tenha sido tão difícil comunicar à Corte alguns outros argumentos-chave sobre diferença cultural e autonomia étnica continua sendo uma frustração.

A decisão da Corte está salpicada de frases que endossam a importância da diferença étnica:

A questão que nos interessa aqui é determinar se a lei familiar do Suriname aplica-se à tribo saramaca. A este respeito a evidência mostra que as leis do Suriname sobre este assunto não têm nenhuma força no que concerne aquela tribo; os membros da tribo não as conhecem e em vez disso são governados por suas próprias normas. $\mathrm{O}$ estado, por sua vez, não mantém na área da tribo as estruturas necessárias ao registro de casamentos, nascimentos e mortes... Além do mais, as disputas que surgem sobre esses assuntos não são submetidas pelos saramacas aos tribunais do Governo, e a intervenção das cortes em tais matérias a respeito dos saramacas virtualmente inexiste. ${ }^{17}$

E em vários pontos o documento tenta definir o costume local, com base no meu depoimento, de forma relativamente detalhada:

Os saramacas têm uma estrutura familiar fortemente matriarcal [sic, para matrilinear] com casos freqüentes de poligamia [poliginia]. O grupo de parentesco primário, chamado de bêè, compõe-se de todas as pessoas descendentes da mesma mulher. Este grupo assume responsabilidade pelos atos de qualquer de seus membros e, teoricamente, cada membro é responsável pela totalidade do grupo. Isso significa que qualquer compensação por danos devida a um membro retorna ao bêè, e o seu representante a distribui entre todos os membros.

17 Neste ponto do seu texto, a corte acrescentou: “A única evidência contrária é a afirmação do Sr. Ramón de Freitas, mas a Corte formou uma impressão da testemunha por causa da maneira como ele deu o seu depoimento, sua atitude durante a audiência, e a personalidade por ele demonstrada no decorrer da mesma, que levou a Corte a desconsiderar seu depoimento."

Horizontes Antropológicos, Porto Alegre, ano 5, n. 10, p. 203-241, maio 1999 
Mas, apesar dessas excursões etnográficas, a Corte deixou de usar plenamente o seu conhecimento recém-adquirido sobre diferenças culturais, quase como se lhe agradasse admitir a existência de, digamos, "matriliniaridade" ou "poliginia" mas fosse incapaz de lidar com suas implicações nas situações em que elas contradizem o que os juízes consideram normas familiares ocidentais "naturais" - ou, como eles disseram, "natureza humana" crua.

Em vários momentos, por exemplo, a Corte sustentou que não era necessário a Comissão demonstrar o que "nós" consideramos sentimentos "naturais" ou relações solidárias de parentesco. Referindo-se à execução das vítimas, eles escreveram, "É da natureza humana que qualquer pessoa sujeita a tais ataques e maltratos experimente sofrimento emocional... (Logo) não há necessidade de prova para chegar a esta conclusão (p. 16). Ou novamente, "Presume-se que os pais tenham sofrido psicologicamente com a morte cruel de seus filhos, porque é da natureza humana que qualquer pessoa sofra por causa do sofrimento de seu filho sob tortura" (p. 24). Mas a Corte não considerou persuasivos os argumentos da Comissão, avançados em grande parte através do meu depoimento, de que na sociedade saramaca uma pessoa pode sentir a mesma dor pelo sofrimento do filho de uma irmã, afirmando necessitar evidência específica de que tais dependentes sofreram psicologicamente - aparentemente o testemunho de um psicólogo/psiquiatra que havia entrevistado as partes em questão. A Corte tampouco aceitou que certos parentes chamados de "dependentes" pela Comissão - pessoas como a irmã ou a irmã da mãe de uma vítima - recebessem compensação por perda de suporte (apesar da sua aceitação de esposas poligínias e seus filhos). "A Corte”, eles escreveram, “está consciente das dificuldades do presente caso: ele envolve uma comunidade que mora na selva, cujos membros são virtualmente analfabetos e não usam documentos escritos. Mesmo assim, outros (não especificados) meios de prova poderiam ter sido usados" (p. 24). Neste aspecto do caso, envolvendo relações de parentesco de família extensa e matrilinear que iam contra as normas ocidentais, os depoimentos etnográficos gerais sobre organização doméstica, combinados com declarações juramentadas caso a caso por parentes saramacas, foram sumariamente declarados insuficientes. ${ }^{18} \mathrm{E}$ dentro do mesmo espírito, para as

18 David Padilla (1995) reagiu com frustração à alegação da Corte de que os dados fornecidos pela Comissão estavam "não suficientemente documentados" escrevendo que "numa cultura e economia em 
pessoas que a Corte designava como "herdeiras" (uma categoria universal e sem problemas para a Corte) em vez de "dependentes" (categoria considerada culturalmente carregada), nenhuma prova especial foi considerada necessária para determinar danos materiais ou psicológicos. Eis aqui como eles conseguiram fazer a triagem entre essas categorias de parentes, fazendo ao mesmo tempo uma concessão simbólica ao costume local e desconsiderando-o na prática (através da aplicação de princípios anti-sexistas universalistas):

Desde que a Convenção No. 169 do ILO sobre os povos tribais e indígenas nos países independentes (1989) não foi aprovada pelo Suriname... princípios genéricos da lei precisam ser aplicados... Por regra comum na maioria das legislações os herdeiros de uma pessoa são seus filhos. É também geralmente aceita a divisão entre esposos dos bens adquiridos durante o casamento... Se não houver filhos nem esposos, a lei particular comum reconhece os ascendentes como herdeiros... Os termos "filhos", "esposo" e "ascendente" devem ser interpretados de acordo com a lei local... (que) no presente caso não é lei surinamesa, porque esta lei não vigora na região, no que diz respeito à lei de família. Por isso, os costumes saramacas devem ser levados em consideração... desde que não estejam em conflito com a Convenção Americana. Assim, ao referir-se a "ascendentes", a Corte não fará nenhuma distinção de sexo, mesmo que isso seja contrário ao costume saramaca. (p. 19).

Deu, como eles dizem, para a matrilinearidade.

Além da área relativamente "segura" da lei de família, onde pela primeira vez levou claramente em consideração a lei consuetudinária, a Corte recuou diante da espinhosa questão da autonomia étnica dentro dos estados nacionais. "A Corte não considera necessário determinar se os saramacas gozam de autonomia jurisdicional e legislativa na região que eles ocupam" (p. 18). O argumento da Comissão de que os militares do Suriname violaram território saramaca, que poderia ter aberto uma caixa de Pandora para países como Brasil, Colômbia ou Peru, foi desconsiderado por uma curiosa tecnicalidade. Como, a Corte argumentou, o tratado de 1762 entre os saramacas e a coroa

que recibos de compras, declaração de impostos e outros meios comuns de verificação não são usualmente empregados, fica difícil determinar que melhores meios poderiam ser fornecidos do que declarações ajuramentadas e não questionadas de membros da família".

Horizontes Antropológicos, Porto Alegre, ano 5, n. 10, p. 203-241, maio 1999 
holandesa, que garantia a liberdade dos saramacas, incluiu artigos especificando o retorno de escravos fugitivos, e como a escravatura é proibida por todas as convenções internacionais modernas de direitos humanos, "um acordo desse tipo não pode ser invocado diante de uma corte internacional de direitos humanos" (p. 18), e todas as reivindicações baseadas neste documento sagrado dos saramacas são insignificantes perante esta Corte. (Seria o caso de perguntar se semelhante arrazoado não invalidaria a Constituição dos Estados Unidos, que também discute o retorno de escravos fugitivos entre estados.) E, agindo presumivelmente com igual motivação, a Corte negou o pagamento de indenização por danos morais ao povo saramaca como um todo, rejeitando o caso da Comissão de que as mortes teriam sido motivadas em parte pelo ódio étnico por falta de provas. ${ }^{19}$ Como David Padilla (1995) comentou recentemente, "Nesta questão [de danos morais ao povo saramaca como um todo] parece que a Corte se perdeu completamente".

Somado ao meio milhão de dólares conferido aos parentes das vítimas, a decisão da Corte citou "o direito das famílias das vítimas de saber onde foram colocados os restos mortais" e observou que "esta obrigação é de especial importância... tendo em vista as relações familiares costumeiras entre os saramacas" (p.3 6). Ela também mandou o Suriname, como compensação adicional, reabrir a escola na aldeia de Guyaba (fechada desde o início da guerra civil em 1986), onde vivem alguns filhos das vítimas, e reabrir o posto de saúde local. ${ }^{20}$

Como em todas as decisões desse tipo - que, por sinal, não admitem apelação - o que não falta são especulações. Teria sido um simples expediente político dos juízes, não tratar da questão legal central dos povos "tribais" dentro de estados nacionais, ou aconteceu algo mais tenebroso? O julgamento

19 A Corte usa consistentemente a palavra "racial" para o que eu chamo de "étnico." Não está claro se eles compreenderam que a Comissão não estava baseando seu argumento em fenótipo - na verdade, os matadores e os mortos eram fisicamente indistinguíveis - mas sim em cultura e política e história.

${ }^{20}$ David Padilla (1995) observa que, "na questão da obrigação do Governo de investigar e punir os responsáveis por aqueles crimes, a Corte ficou em total silencio apesar do seu próprio veredicto em Velásquez Rodrigues v. Honduras sobre exatamente o mesmo ponto. Lá a Corte manteve: O Estado tem o dever legal de tomar medidas razoáveis para prevenir violações aos direitos humanos e de usar os meios disponíveis para efetuar uma investigação séria das violações cometidas dentro de sua jurisdição, de identificar os responsáveis, de impor a punição apropriada e assegurar uma compensação adequada à vítima. Para. 174.”

Horizontes Antropológicos, Porto Alegre, ano 5, n. 10, p. 203-241, maio 1999 
(p. 12-13) faz referência a decisões da Corte, tomadas depois da audiência final em Costa Rica, "de utilizar os serviços especializados" de dois surinameses "para obter informação mais completa," da qual apenas uma parte chegou a ser mostrada à Comissão, e de enviar o secretário assistente da Corte ao Suriname para uma visita de uma semana com o mesmo propósito. Há razão para crer que a informação colhida por esses meios, que a Comissão não teve oportunidade de rebater e parte da qual pode ter vindo, sem o conhecimento da Corte, de fontes próximas dos militares, possa ter sido o fator de desequilíbrio que levou a Corte a não aceitar os argumentos da Comissão sobre a natureza da autonomia quilombola no Suriname. Mas nós provavelmente nunca saberemos com certeza.

Hoje, o Governo (e os militares) do Suriname, ocultando sua corrupção moral sob um fino verniz de democracia, parece mais determinado do que nunca a apagar a história quilombola, abolir unilateralmente suas obrigações por tratado, e lucrar através de esquemas financeiros ilegais com a exploração de terras quilombolas (ver Price, 1998). Muitos anos atrás, os chefes dos grupos quilombolas foram pressionados pelo Governo a emprestar seus nomes ao Acordo de Paz de Agosto de 1992 (Akkoord voor Nationale Verzoening en Ontwikkeling), encerrando oficialmente a guerra civil que já durava seis anos. Eles terminaram assinando, mas durante uma visita oficial subsequente que fizeram à Holanda, eles pediram esclarecimentos sobre os "direitos de terra e títulos" mencionados naquele documento e mais uma vez reivindicaram autoridade tradicional sobre o interior do Suriname. O Acordo de Paz de 20 páginas gasta muitas de suas palavras em questões de direitos fundiários, minerais e de recursos naturais - todos eles reivindicados sem ambigüidade pelo estado. O documento não deixa dúvida de que o Governo embarcou num programa rigoroso, em relação às suas minorias quilombolas e ameríndias, de unificação, uniformização e apropriação legal. O governo insiste que sob a lei surinamesa, nem quilombolas nem povos indígenas detêm qualquer direito especial e que "os interesses do desenvolvimento total do país" - que cada vez mais significa os interesses particulares de funcionários do governo e seus camaradas - vêm primeiro. Recentes relatórios de observadores de ONGs descrevem uma triste situação (ver também Colchester, 1995). 
[21 de agosto de 1996] A comunidade quilombola saramaca de Nieuw Koffiekamp enfrenta uma ameaça de realocação para dar lugar a uma mina de ouro multinacional, sendo implantada pela Golden Star Resources de Denver, Colorado, e Cambior Inc. de Montreal. A comunidade quilombola está contestando a realocação e exigindo que as companhias negociem com eles como proprietários tradicionais da terra. A Golden Star construiu inúmeros portões e outras barreiras, inclusive uma enorme parede de terra, para restringir os movimentos dos membros da comunidade nas suas terras, negando-lhes acesso às suas lavouras, seus domínios de caça e seus locais sagrados. A polícia do Suriname e as forças de segurança da companhia estabeleceram sua presença, colaborando estreitamente entre si. Na verdade, o chefe de segurança da Golden Star é o comandante do destacamento policial da mina de Gros Rosebel e equipou o pessoal de segurança da Golden Star com armas exclusivas da polícia. Uma unidade fortemente armada do Grupo de Apoio Policial anti-terrorista de elite também está no local. Os oficiais da segurança ameaçaram, intimidaram e investiram contra membros da comunidade. Em várias ocasiões, as patrulhas abriram fogo sobre as cabeças dos habitantes de Nieuw Koffiekamp, mesmo enquanto estes cultivavam lavouras e buscavam alimentos na floresta. (World Rainforest Movement, 1996).

[20 de abril de 1998] Os líderes de vinte e três aldeias quilombolas saramacas reuniram-se na comunidade de Piki Seei nos dias 13 e 14 de março de 1998 para discutir direitos de terra e as incursões de uma companhia madeireira chinesa. Os líderes de aldeia afirmaram inequivocamente que se opõem às operações da companhia chinesa NV Tacoba (a.h.a. Tacoba Forestry Consultants), dentro ou nas proximidades de suas terras ancestrais, e querem seus direitos às terras ancestrais, definidos por lei internacional de direitos humanos totalmente reconhecida. $\mathrm{O}$ atual governo do Suriname afirma que não tem obrigações legais sob os tratados [do século dezoito] com os quilombolas e não reconhece os seus direitos de posse sobre as suas próprias terras ancestrais. Além disso, fez ou está processando a concessão de vastas áreas de floresta a companhias madeireiras e mineradoras multinacionais. Essas concessões são feitas sem notificar as comunidades indígenas e quilombolas, e muito menos buscar sua participação ou aprovação, mesmo quando as aldeias ficam dentro das concessões. Atualmente, pelo menos dois terços das comunidades indígenas e quilombolas (que abrigam mais de 50 mil pessoas] estão dentro ou muito próximas de concessões madeireiras e mineradoras. Os líderes saramacas só se deram conta de que havia 
concessões nos seus territórios quando um grupo de "chineses de língua inglesa" chegou às comunidades de Nieuw Aurora e Guyaba informando-lhes que iam começar a operação de derrubar árvores. As comunidades descobriram mais tarde que a Tacoba e outras madeireiras tinham recebido concessões múltiplas dentro e nas proximidades de seu território. Há rumores de que a companhia indonésia Barito Pacific também está adquirindo uma concessão de 600.000 hectares em territórios quilombolas saramaka e ndyuka, que vai do Suriname central até o rio Marowijne. Representantes da Barito visitaram aquela área recentemente (Jai Kreek) acompanhados por tropas e helicópteros do exército nacional surinamês, carregando uma carta assinada pessoalmente pelo presidente do Suriname. Aparentemente, o negócio com a Barito foi assinado quando o presidente Surinamês estava na Indonésia em setembro último. Nenhuma dessas concessões foi aprovada pela Assembléia Nacional. Pouco se sabe sobre a NV Tacoba, embora suspeite-se que seja uma companhia estatal chinesa, incorporada localmente no Suriname. A Tacoba é também conhecida por suas relações com o ex-ditador militar Desi Bouterse, ativo negociante em madeira como comprador para terceiros, e com outros membros do partido do governo Surinamês, o Partido Democrático Nacional. Recentemente o Suriname abriu uma embaixada na China e está procurando expandir ali seus negócios e relações de ajuda. A Tacoba parece ser o primeiro grande investimento chinês no Suriname. Uma das concessões da Tacoba inclui a comunidade saramaca de Duwata. Sabe-se que representantes da Tacoba disseram aos líderes da aldeia que a comunidade deles não tinha permissão para usar a floresta a mais de um quilômetro da aldeia, pois a área era agora uma concessão da Tacoba. Atualmente, toda a terra no interior do país (aproximadamente 80\%) está classificada como terra do estado, e os povos indígenas e quilombolas são considerados ocupantes de terra do estado, sem direitos nem títulos de propriedade. Se as suas atividades de subsistência estiverem em conflito com as operações de madeireiras ou mineradoras, estas têm precedência por uma questão de lei. Além disso, a lei do Suriname não apresenta nenhum mecanismo de consulta às comunidades sobre a entrega de concessões dentro ou perto de seus territórios. As regras internacionais de direitos humanos dão aos povos indígenas e quilombolas o direito de participar plenamente das decisões, antes delas serem tomadas, sobre se haverá concessões em suas terras. Este direito inclui o direito a informação sobre as atividades propostas, as companhias envolvidas, e a natureza dos riscos apresentados pela atividade. Os quilombolas Matawai agora têm de importar água do litoral porque os seus rios e riachos foram poluídos pelas mineradoras, e eles dizem que têm pegado peixes de olhos opacos e com tumores. (Forest Peoples Programme, 1998). 
Como já escrevi (Price, 1998), antropólogos preocupados - quase todos de nacionalidade estrangeira e muitos deles suficientemente críticos do regime militar Surinamês para serem efetivamente impedidos de entrar no país - foram incapazes de fazer muito mais do que testemunharem sobre a recente devastação e o abuso dos direitos humanos. Devido às relações de poder dentro do país, não se sabe quem terá a coragem e os meios para socorrer os quilombolas e índios em luta para preservar a sua identidade como povos distintos. O que parece necessário é legislação rápida, para alinhar a constituição e o código legal do Suriname às várias convenções de direitos humanos das quais o país já participa, e que o governo compreenda que o tratamento dado aos povos quilombolas e indígenas outorga ao Suriname a vergonhosa distinção de ser "o único estado no hemisfério ocidental onde vivem povos indígenas [e quilombolas] que não reconhece de alguma forma os seus direitos de possuir os territórios de seus ancestrais" (Forest Peoples Programme, 1998). Para os estudantes da Afro-América, os quilombolas do Suriname têm sido há muito tempo um símbolo de resistência heróica e um exemplo de criatividade cultural diaspórica a longo prazo. Mas a República do Suriname adotou claramente um programa unilateral para abolir os tratados quilombolas do século dezoito e apagar os feitos históricos desses que são os maiores grupos quilombolas sobreviventes nas Américas. No caso do Suriname, a politica governamental atual é, no meu ponto de vista, equivalente a etnocídio.

(Traduzido do inglês por José Fonseca)

\section{Referências}

AMNESTY INTERNATIONAL. Suriname: violations of human rights. London, 1987.

BILBY, K. M. The remaking of the Aluku: culture, politics, and Maroon ethnicity in French South America. Unpublished Ph.D. dissertation. Johns Hopkins University, 1990. 
BILBY, K. M. Swearing by the past, swearing to the future: sacred oaths, alliances, and treaties among the Guianese and Jamaican Maroons. Ethnohistory, n. 44, p. 655-689, 1997.

BINDER, D. Diplomacy and public relations: image maker aids new democracy. The New York Times, New York, Jan. 25, 1988.

BRANA-SHUTE, G. On the corner: male social life in a Paramaribo Creole neighborhood. Assen: Van Gorcum, 1979.

BRANA-SHUTE, G. An inside-out insurgency: the Tukuyana Amazones of Suriname. In: SUTTON, P.; PAYNE, A. (Ed.). Size and survival: the politics of security in the Caribbean and the Pacific. London: Frank Cass, 1993. p. 5469 .

CERQUONE, J. Flight from Suriname: refugees in French Guiana. Washington: U.S. Committee for Refugees, 1987.

CHIN, H. E.; BUDDINGH', H. Surinam: politics, economics and society. London: Frances Pinter, 1987.

DEW, E. The difficult flowering of Surinam: ethnicity and politics in a plural society. The Hague: Martinus Nijhoff, 1978.

FOREST PEOPLES PROGRAMME. Suriname: Saramacca Maroons say no to multinational logging. Press release. 20 Apr. 1998.

FRANSZOON, A. Crisis in the Backlands. Hemisphere, v. 1, n. 2, p. 36-38, 1989.

IN MEMORIAM HERMAN EDDY GOODING: viribus audax, manmoedig door innerlijke kracht. Paramaribo: Moiwana'86, 1992. 
MEEL, P. Money talks, morals vex: the Netherlands and the decolonization of Suriname, 1975-1990. European Review of Latin American and Caribbean Studies, n. 48, p. 75-98, 1990.

MEMRE MOIWANA. Paramaribo: Moiwana'86, 1990.

MENSENRECHTEN 1991 SURINAME. Paramaribo: Moiwana'86, 1992.

MUNNEKE, H. F. Customary law and national legal system in the Dutchspeaking Caribbean, with special reference to Suriname. European Review of Latin American and Caribbean Studies, n. 51, p. 91-99, 1991.

NOWAK, M. Suriname: an International Alert report. London: International Alert, 1989.

OAS. Report on the situation of human rights in Suriname. Washington, 1983. (OAS/Ser.L/II.61/Doc.6 rev. 1, October 5).

OAS. Second report on the human rights situation in Suriname. Washington, 1985. (OAS/Ser.L/II.66/ Doc.21 rev. 1, October 2).

OAS. Annual report of the Inter-American Commission on Human Rights 1989-1990. Washington, 1990. (OAS/Ser.L/V/n.77 rev.1/Doc.7, 17 May).

OAS. Annual report 1991: Inter-American Commission on Human Rights. Washington, 1992. (OAS/ Ser.L/VÆ1.81 rev.1/Doc.6, 14 February).

OOSTINDIE, G. The Dutch Caribbean in the 1990s: decolonization or recolonization?. Caribbean Affairs, n. 5, p. 103-119, 1992.

PADILLA, D. J. Reparations in Aloeboetoe v. Suriname. Human Rights Quarterly, 1995. 
POLIMÉ, T. S.; THODEN VAN VELZEN, H. U. E. Vluchtelingen, opstandelingen en andere Bosnegers van Oost-Suriname, 1986-1988. Utrecht: Instituut voor Culturele Antropologie, 1988.

PRICE, R. First-time: the historical vision of an Afro-American people. Baltimore: Johns Hopkins University Press, 1983a.

PRICE, R. Saramaka wars. Ann Arbor: Karoma, 1983b.

PRICE, R. To slay the Hydra: Dutch colonial perspectives on the Alabi's World. Baltimore: Johns Hopkins University Press, 1990.

PRICE, R. Executing ethnicity: the killings in Suriname. Cultural Anthropology, n. 10, p. 437-471, 1995.

PRICE, R. Scrapping Maroon history: Brazil's promise, Suriname's shame. New West Indian Guide, n. 72, p. 233-255, 1998.

PRICE, R.; PRICE, S. On the mall: presenting Maroon tradition-bearers at the 1992 FAF. Bloomington: The Folklore Institute, Indiana University, 1995.

PRICE, S.; PRICE, R. Maroon arts: cultural vitality in the African diaspora. Boston: Beacon Press, 1999.

QUINTUS BOSZ, A. J. A. Drie eeuwen grondpolitiek in Suriname. Assen: Van Gorcum, 1954.

QUINTUS BOSZ, A. J. A. De rechten van de bosnegers op de ontruimde gronden in het stuwmeergebied. Surinaams Juristenblad, n. 5, p. 14-21, 1965.

SCHOLTENS, B. Bosnegers en overheid in Suriname: de ontwikkeling van de politieke verhouding 1651-1992. Paramaribo: Afdeling Cultuurstudies: Minov, 1994. 
STEDMAN, J. G. Stedman's Surinam: life in an eighteenth-century slave society. Edited by Richard Price \& Sally Price. Baltimore: Johns Hopkins University Press, 1992.

THODEN VAN VELZEN, H. U. E. Ten geleide and Militaire patstelling beheerst Suriname. In: POLIMÉ, T. S.; THODEN VAN VELZEN, H. U. E. Vluchtelingen, opstandelingen en andere Bosnegers van Oost-Suriname, 1986-1988. Utrecht: Instituut voor Culturele Antropologie, 1988. p. 7-25.

THODEN VAN VELZEN, H. U. E. The Maroon insurgency: anthropological reflections on the civil war in Suriname. In: BRANA-SHUTE, G. (Ed.). Resistance and rebellion in Suriname: old and new. Williamsburg: College of William and Mary, 1990. p. 159-188.

WAKO, S. A. Visit by the special rapporteur to Suriname. Geneva: Commission on Human Rights, Economic and Social Council of the United Nations, 1985. (E/CN.4/1985/17, Annex V).

WAKO, S. A. Summary or arbitrary executions: report by the special rapporteur. Geneva: Commission on Human Rights, Economic and Social Council of the United Nations, 1988. (E/CN.4/1988/22,19 January).

WESTERLOO, G. van; DIEPRAAM, W. Frimangron. Amsterdam: De Arbeiderspers, 1975.

WORLD RAINFOREST MOVEMENT. Urgent action Suriname. 21 Aug. 1996. Internet text.

ZWAMBORN, M. Suriname. In: HUMAN RIGHTS IN DEVELOPING COUNTRIES. Utrecht: Studie- en Informatiecentrum Mensenrechten, Rijksuniversiteit te Utrecht, 1992. p. 1-30. 